\title{
MONITORING PROPOSAL OF THE SPECIES MONTANE GUINEA PIG IN PERU
}

Faculty of Animal Breeding, Bioengineering and Conservation, Warsaw University of Life Sciences-SGGW, Warszawa, Poland

\begin{abstract}
The work presents a proposal for the monitoring of a species of medium size South American rodent - Montane Guinea Pig. The population of this species is not constantly monitored, so it is impossible to determine exactly how many individuals are in the wild. In recent years, the area of its habitat has been significantly reduced. Therefore, it was necessary to develop methods of its monitoring. Monitoring has been proposed in several areas of its occurrence: the province of the Lima district - Cercado de Lima, the Junín National Reserve, and the province of the city of Ambo. The main aim of the article is to define population status indicators, habitat quality indicators, and to establish examples of dates and frequency of tests.
\end{abstract}

Key words: Montane Guinea Pig, monitoring, rodent, population, indicator.

\section{INTRODUCTION}

Montane Guinea Pig is a medium-sized rodent (rodentia). It grows up to about $250 \mathrm{~mm}$ in length and weighs about 600-700 grams. It has a strong, cylindrical body and short limbs characteristic of the caviidae family. It has no tail. The color of the hair of individuals of this species depends on the place of occurrence (in Peru, the hair on the back surface is dark reddish-brown mixed with black, and the lower parts are dark gray; in Chile, the hair is light brown, with lighter pants; in Bolivia, the color of the upper body is olive gray agouti, the lower one is creamy white or white). It has a hypselodent dentition - growing throughout life, with the tooth formula 1/1, 0/0,1/1,3/3) (Ortizet et al. 2012). Montane Guinea Pig is active around the clock. They are usually most active at dusk and dawn. It is related to the presence of predators. Their activity is mainly related to the search for food, as well as marking and exploring the territory. They are herd animals, usually forming groups of several females with one large dominant male. Montane Guinea Pig males are very territorial (in nature there are frequent fights for domination). These rodents do not dig their burrows by themselves, but only take over the abandoned hideouts of other animals (Eisenberg and Redford 1999). Montane Guinea Pig, like all species of the genus Cavia, is a ruthless herbivore. Its diet consists mainly of thick vegetation - leaves of trees and grass (they have teeth that allow

Corresponding author: Adrianna Kędra, Faculty of Animal Breeding, Bioengineering and Conservation, Warsaw University of Life Sciences-SGGW, Jana Ciszewskiego 8, 02-786 Warszawa, Poland, e-mail: adr_ked@wp.pl 
them to chew on hard plant material, a rich intestinal flora necessary for digesting it, and a long digestive system). Seeds, tubers, plant roots, and alpine herbs may also form part of their diet (Eisenberg and Redford 1999). Predator mortality in adults of this-species is approximately $50 \%$. In the natural environment, there are about 20 potential - predators hunting these rodents - birds of prey, e.g. common hawk, gray-headed lepton, black-bellied caracar, light-headed caracar, earthen owl, buzzard, striped buzzard, American kite, red-tailed falcon, American kestrel, mammals, e.g. Greater Grisons, Lutrino Opossum, Domestic Cat, Great Ocelot, Crab-eating Majkong, Domestic Dog and Reptiles, e.g. Boa Constrictor, Common Commoners, Terrible Rattlesnake, Green Anaconda, Brazilian Teu (Dunnum et al. 2015). Montane Guinea Pig is a rodent characteristic of the steppes of the neotropical land. It is a typical terrestrial herbivore. Individuals of this species prefer a grassy or shrub-grass plant formation. Open areas with access to water and dense, high vegetation provide shelter from predators for these small mammals. Their strategy is to hide vegetation in tunnels and remain completely still in the presence of predators (freazing). The pampa plant cover, which is the range of these rodents, is dominated by grasses, including the characteristic Cortaderia selloana, perennials and annual plants. Trees are rare and occur mainly along river banks. There are also root crops, wastelands or meadows in the vicinity of the area where the Montane Guinea Pig is found. Specimens of this species are also sporadically found in riparian forests, inland wetlands and overgrown high-mountain Andean grasslands (Candel 2019).

From 1996 to 2006, this species was grouped in the LR (lower risk) category, which is lower risk, which corresponds to the current classification as NT (close to threat). In 2006 its categories were changed to LC, motivating this decision by its widespread use (www.iucnredlist.org). It is presumed that there is a large population of these animals in the wild and it is unlikely that this species will decline at a rate that would qualify it for inclusion in another threat category. However, the habitat of these animals is declining and in recent years there has been a continuous decline in the number of mature individuals. Montane Guinea Pig is native to the high Andes of South America. The species' range stretches from Peru to Chile and Argentina (Fig. 1). It lives at an altitude of 2.000 to 4.500 meters above sea level. Its habitat is quite humid, with numerous rocks and thickly leafy vegetation. It lives in inland wetlands, forests and agricultural land used for the cultivation of grasses (meadows and pastures) or other herbaceous crops. The range of this species also partly coincides with the range of the Brazilian Cavia aperea. This is due to the fact that these species are very closely related (once even Cavia tschudii was not considered a separate species, it was classified as a subspecies Cavia aperea). The aim of this study was to propose methods of monitoring the species Cavia tschudii, belonging to Caviidae family. 


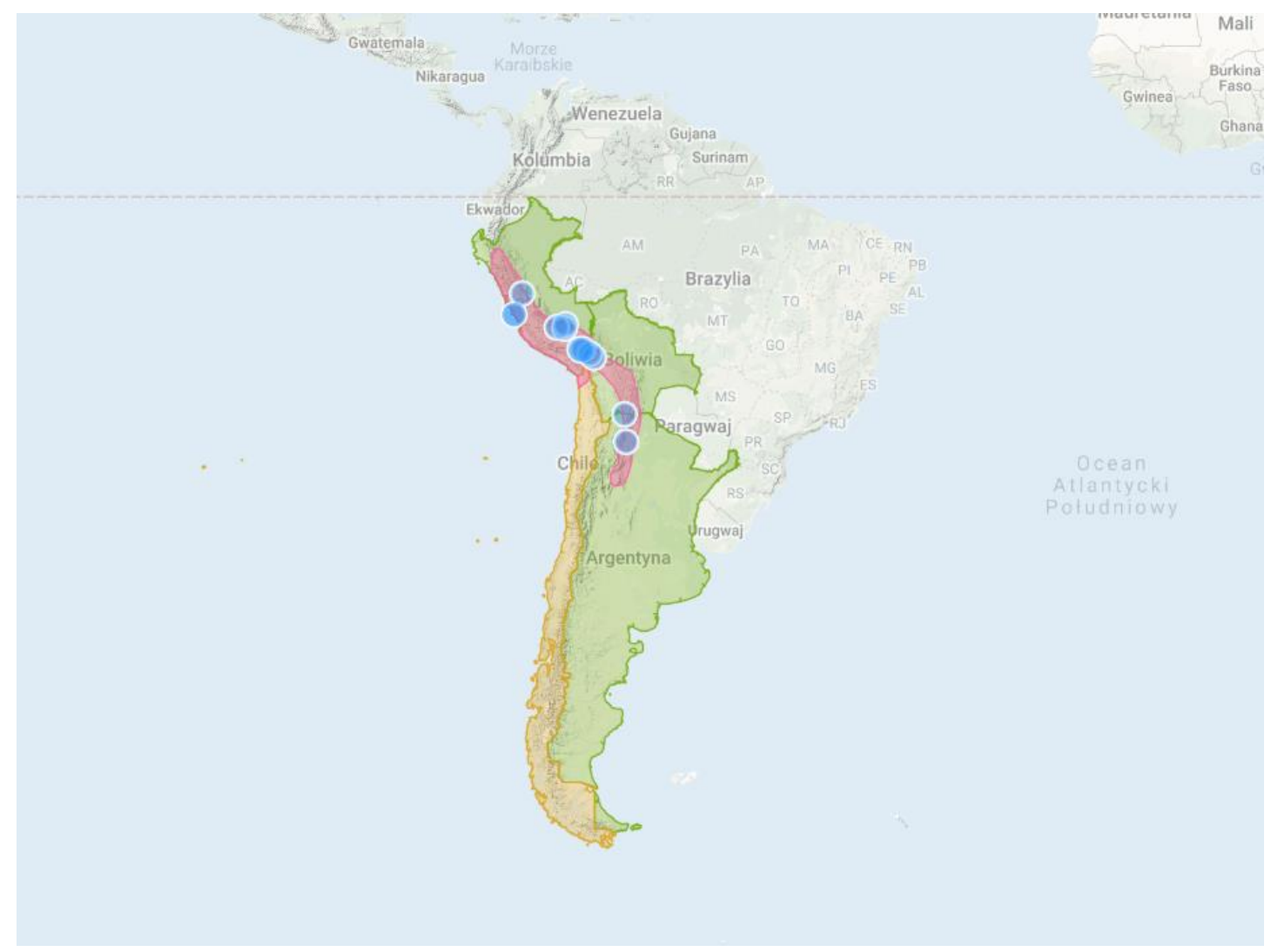

Fig. 1. Range of occurrence of Cavia tschudii: green color - low population density, red color - high population density, blue color - animals recorded in photos

Source: Cavia tschudii, https://www.inaturalist.org/taxa/43810-Cavia-tschudii, access: 9.11.2020.

\section{CURRENT DISTRIBUTION AREA}

The population of the Montane Guinea Pig is not monitored on an ongoing basis in the areas of occurrence. So it is not known exactly what its condition is as of today. Information from observers and scientists studying protected areas where this species occurs shows a decline in the number of adults. It is also known that recently there has been a gradual degradation and reduction of the habitat of these animals, which reduces the size of the population (rodents must gather in a smaller area, which causes more frequent fights between individuals of this species, and increases the pressure of predators). It was therefore necessary to monitor the populations of Peru, Argentina and Chile in order not to excessively deplete this species. So far, no conservation measures have been taken in South America. Monitoring has been proposed, the main purpose of which is to track the situation of the Motane Guinea Pig population in the country (Peru) at selected sites from the current distribution area: province of Lima district - Cercado de Lima (Fig. 2), Junín National Reserve (Fig. 3), and the province of the city of Ambo (Fig. 4). 


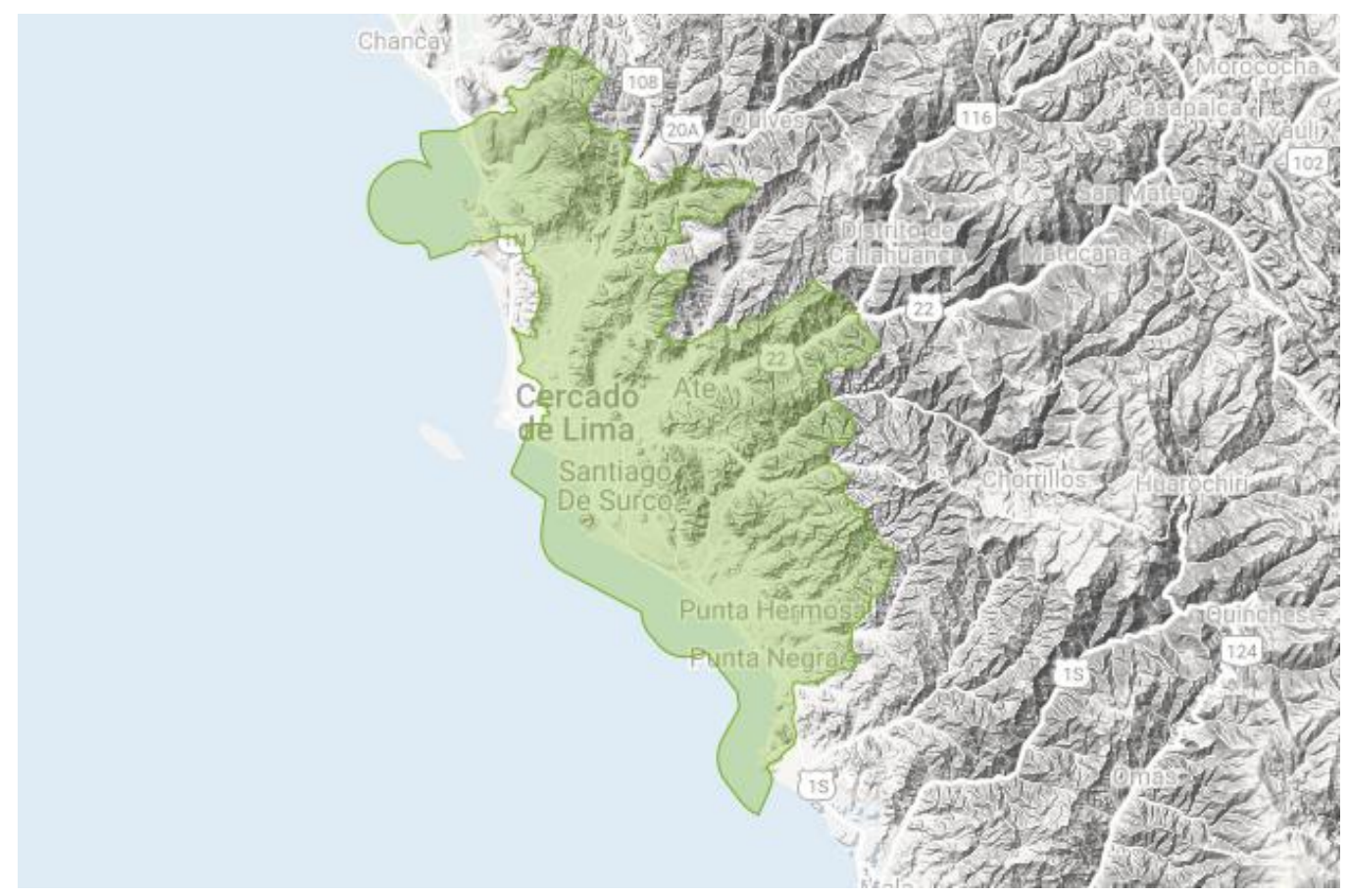

Fig. 2. The monitoring area in the province of Lima - Cercado de Lima is marked in green Source: Cavia tschudii, https://www.inaturalist.org/taxa/43810-Cavia-tschudii, access: 9.06.2020.

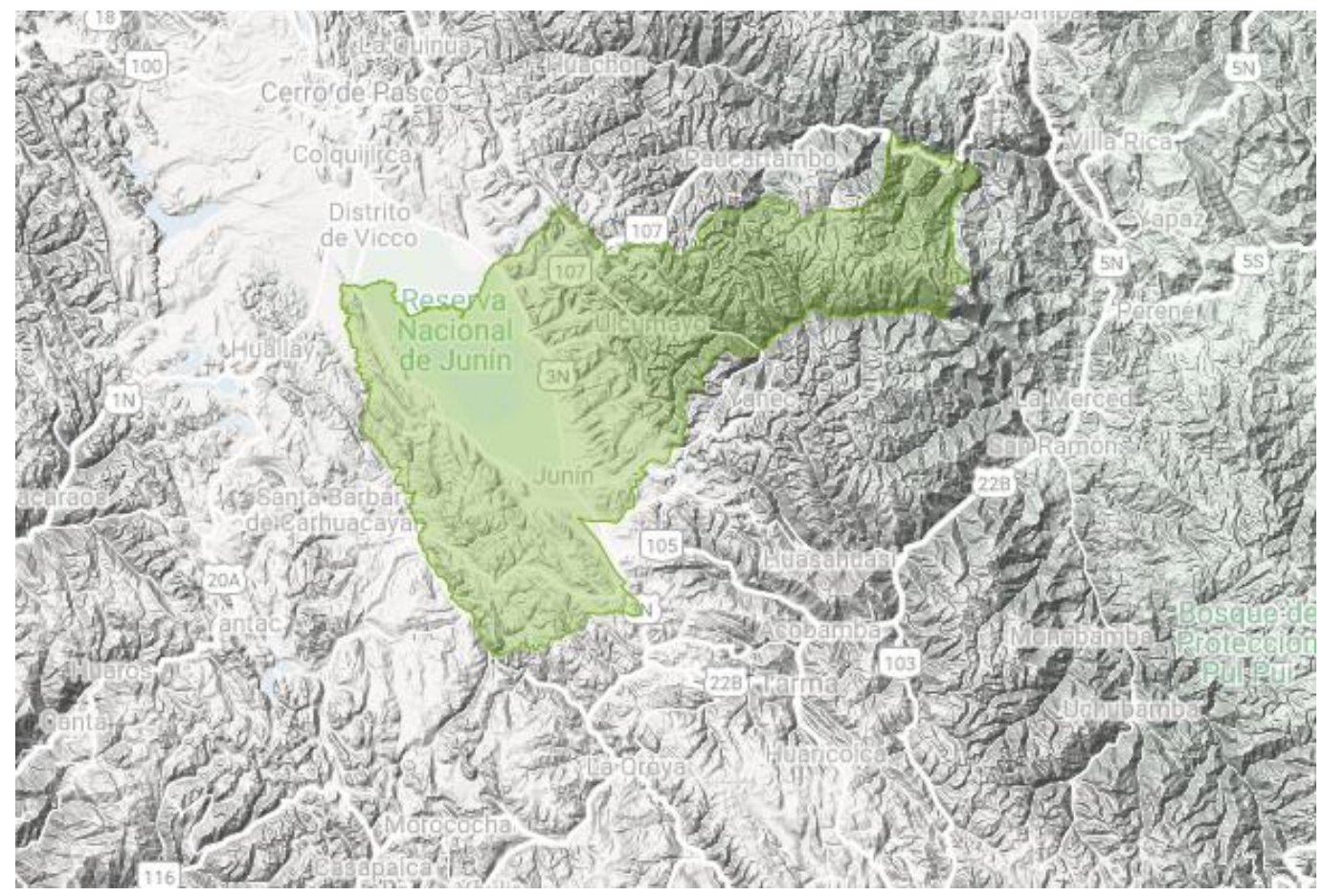

Fig. 3. The monitoring area in the Junín National Reserve is marked in green

Source: Cavia tschudii, https://www.inaturalist.org/taxa/43810-Cavia-tschudii, access: 9.06.2020. 


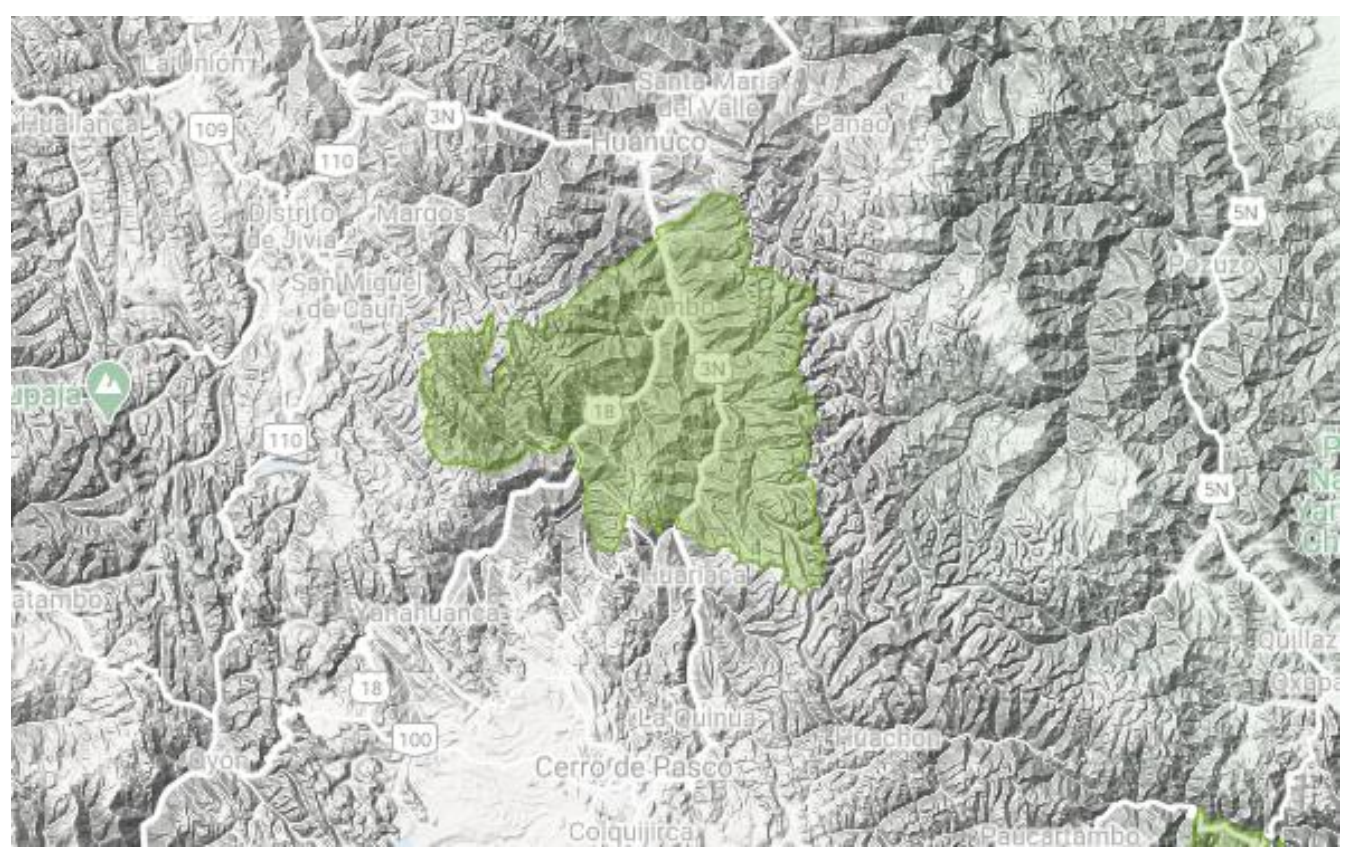

Fig. 4. The monitoring area in the province of Ambo is marked in green

Source: Cavia tschudii, https://www.inaturalist.org/taxa/43810-Cavia-tschudii, access: 9.06.2020.

Selected sites are representative of the continental region and the current range of Montane Guinea Pig in Peru. The next monitoring should also take into account the positions concerning Chile and Argentina. As part of the monitoring, it will be monitored whether and to what extent the features of the living environment that are important for the Montane Guinea Pig are changing. The environmental factors that potentially affect the presence or disappearance of this species are not fully understood. Therefore, monitoring will be crucial for their determination. However, the knowledge of the species biology shows that the presence of corridors in dense vegetation is an overriding factor. Therefore, monitoring should cover the area covered with grasses (in particular pampas grass, which is the main component of the food base of these animals). Whether or not an area is inhabited by coffee will also be determined by the tracks left by it.Detailed monitoring of these sites together with the monitoring of other sites will give a better idea of the habitat requirements of the species. The assessment of the size of the population will require catching in live traps (the method of marking and re-catching - CMR). This method is commonly used in ecology to estimate the size of an animal population, where it is impractical to count each individual separately. Part of the population is captured marked with a harmless sign (bleaching the fur on small fragments on the back with $30 \% \mathrm{H}_{2} \mathrm{O}_{2}$ hydrogen peroxide) and released back into the population. Then, after a certain period of time, another trapping of individuals is made. The number of specimens in the sample with the designation, and those observed for the first time, is counted. In subsequent monitoring, the method with the use of telemetry transmitters can also be used, which has already been successfully used in the study of a closely related species, which is the Brazilian guinea pig (Asher et al. 2004). The adopted monitoring concept may, however, change along with the experience gained from the ongoing monitoring and its subsequent stages. 


\section{SELECTION OF MONITORING AREAS AND THEIR SUGGESTED SIZE}

Initially, monitoring should cover 8 sites where the presence of the species was found (province of the Lima district - Cercado de Lima, Junín National Reserve, and the province of the city of Ambo). The monitoring site must consist of two elements: a protective zone with tall and dense vegetation, which animals use as protection against predators, and open areas used for feeding. Monitoring works are carried out on an area of 10 hectares designated within the site. The first step is to confirm the presence of Montane Guinea Pig at the stand. This is done by direct observation of the animal's tracks. After identifying them, you can start designating the monitoring area (it can be square or rectangular). The surface should contain as many characteristic elements of the tested environment as possible (it should contain both the open part of the area, dense vegetation and riparian forests). The boundary of the area should be determined using GPS.

\section{DETERMINING POPULATION STATUS INDICATORS}

Abundance. The method of determining the presence of Montane Guinea Pig is the tagging and re-catch (CMR) method. It consists in catching Montane Guinea Pig in zig zag placed in dense vegetation, where there is a complex network of this animal's corridors. Then the animals are unstably labeled with a $30 \%$ hydrogen peroxide solution and released into the environment. Commonly used cage-type restraints, eg Sherman, should be used for catching. Transects must first be determined 10 to 20 meters wide, then set up the traps and mark their location on the map using GPS. Traps should be checked approximately 3 times a day and moved to a different location every 4 days. After 16 days, they should return to the place of the first catch. Research should be performed by specialists, as there is a possibility of confusing Montane Guinea Pig with Brazilian Guinea Pig (their areas of occurrence overlap).

\section{DETERMINATION OF HABITAT STATUS INDICATORS}

Type of terrain. Specify whether the selected surface is an area:

- open - the open area consists mainly of meadows with pampas grass over $50 \mathrm{~cm}$ high; very few terrain elements are absent or present up to $10 \%$ in this area (e.g. roads);

- partially covered - the coverage is up to $50 \%$ of elements such as riparian forest, thickets, buildings, roads, etc :;

- closed - over $50 \%$ is covered with a significant number of terrain elements: riparian forests, water reservoirs, ditches, ravines, fences, buildings, roads, etc.

The height of the vegetation. The height of the vegetation should also be determined. Montane Guinea Pig need dense and tall vegetation to hide from predators. Vegetation more than $50 \mathrm{~cm}$ high means satisfactory condition, $10-50 \mathrm{~cm}$ - unsatisfactory, and below $10 \mathrm{~cm}-$ bad condition.

Food base. Specify the\% ground cover value for grasses, especially Cortaderia selloana, which are the main food base of Mountain Caviar. From 0-25\% means a poor food base, 25-50\% - medium, 50-100\% - rich. 


\section{TIME AND FREQUENCY OF TESTS}

Monitoring of this species should be carried out from September to March during the main reproductive season of this species. During this period, the size of the population is the largest. It is recommended to carry out monitoring at least every 3 years (due to the reduction of the areas of occurrence of this species).

\section{EQUIPMENT AND MATERIALS FOR RESEARCH}

The following equipment will be necessary to carry out detailed monitoring according to the proposed method:

- Sherman traps,

- GPS,

- measure $20 \mathrm{~m}$ long,

- camera,

- map,

- $30 \%$ hydrogen peroxide solution,

- off-road vehicle.

\section{INDICATORS}

The evaluation system is taken from the methodological guide (Makomaska-Juchiewicz 2015). Indicators of the population's state are shown in Table 1.

Table 1. Cavia tschudii population status indicator

\begin{tabular}{lll}
\hline \multicolumn{1}{c}{ Indicator } & Measure & Means of measurement / determination \\
\hline $\begin{array}{l}\text { Population } \\
\text { density }\end{array}$ & $\begin{array}{l}\text { individual / } \\
\text { ha }\end{array}$ & $\begin{array}{l}\text { The average density of specimens calculated on the basis of the results } \\
\text { of catches using the CMR method at monitoring sites / plots (the number } \\
\text { of cavies caught at all sites refers to their total area) }\end{array}$ \\
\hline
\end{tabular}

Adopted valorization of the status indicators of the population is presented in Table 2 . Cardinal indicators have not been determined.

Table 2. Valorization of the population Cavia tschudii status indicator

\begin{tabular}{cccc}
\hline \multirow{2}{*}{ Indicator } & \multicolumn{3}{c}{ Rating } \\
\cline { 2 - 4 } & FV & U1 & U2 \\
\hline Population density & $>12.5$ individual/ ha & $>0-12.5$ individual / ha & 0
\end{tabular}

FV - proper condition, U1 - condition unsatisfactory, U2 - bad condition. 
The final assessment of the population's condition is determined by the lower of the assessments defined for individual indicators. Component indicators of the quality of the habitat are shown in Table 3a. Valorization of the components of habitat quality indicators are shown in Table 3b. Valorization of the collective indicator of the habitat status are shown in Table 4.

Table 3a. Component indicators of the quality of the habitat

\begin{tabular}{lcl}
\hline \multicolumn{1}{c}{ Component } & Measure & \multicolumn{1}{c}{ Means of measurement / determination } \\
\hline Type of terrain & $\begin{array}{l}\text { descriptive } \\
\text { component }\end{array}$ & $\begin{array}{l}\text { Passing the area on which the designated area is located to one } \\
\text { of } 3 \text { classes: open, partially closed, closed }\end{array}$ \\
\hline $\begin{array}{l}\text { The height of the } \\
\text { vegetation }\end{array}$ & $\mathrm{cm}$ & $\begin{array}{l}\text { The average height of the vegetation on the site measured in the trapping } \\
\text { points }\end{array}$ \\
\hline Food base & $\%$ & $\begin{array}{l}\text { Determine the relative (\%) cover of the land with grasses (in particular } \\
\text { Cortaderia selloana) constituting the main food base of the mountain } \\
\text { coffee }\end{array}$
\end{tabular}

Table 3b. Valorization of the components of habitat quality indicators

\begin{tabular}{lccc}
\hline \multicolumn{1}{c}{ Component / Score } & 0 & 0.5 & 1.0 \\
\hline Type of terrain & open area & partly open area & closed area \\
\hline The height of the vegetation & $<10 \mathrm{~cm}$ & $10-50 \mathrm{~cm}$ & $>50 \mathrm{~cm}$ \\
\hline Food base & $0-25 \%$ & $>25-50 \%$ & $>50-100 \%$
\end{tabular}

Table 4. Valorization of the collective indicator of the habitat status

\begin{tabular}{lccc}
\hline \multicolumn{1}{c}{ Component / Score } & FV & U1 & U2 \\
\hline $\begin{array}{l}\text { Summary indicator } \\
\text { of the quality of the habitat }\end{array}$ & $\geq 3,0$ & $1.2-1.6$ & $\leq 1.1$ \\
\hline
\end{tabular}

FV - proper condition, U1 - condition unsatisfactory, U2 - bad condition.

Only one indicator is used to assess the condition of the population, therefore its assessment is an assessment of the condition of the population.

\section{PROTECTION PERSPECTIVES}

The assessment of the species protection prospects is a forecast of the species population and the condition of its habitat in the perspective of 10-15 years, taking into account all current impacts and anticipated threats that may affect the future condition of its population and habitat in the studied site. The prospects for the maintenance of the species in a given habitat and its protection are assessed as appropriate (FV) in those sites where the density of specimens is above 12.5 per $1 \mathrm{ha}$, and the habitat conditions are favorable for the survival of the population (the area is closed, the vegetation is over $50 \mathrm{~cm}$, and Cortaderia selloana's relative land cover remains above 50\%). The unsatisfactory (U1) or bad (U2) prospects for the protection of the species are related to the changes taking place in the habitat (mowing meadows resulting in a decrease in the height of vegetation and the disappearance of the food base of Cortaderia selloana). Another factor is the pressure of predators which increases in proportion to the decrease in the area of the habitat. 


\section{GENERAL EWALUATION}

The conservation status of a species at a site should be determined based on the assessment of the population, habitat and conservation prospects of the species at a site, with the lowest of the three assessments being the decisive factor.

\section{MOST IMPORTANT CURRENT AND ANTICIPATED IMPACTS (THREATS) ON THE SPECIES AND ITS HABITAT}

A list of the most important current and anticipated impacts (threats) on the species and its habitat at the site studied (including the current use, planned investments, planned changes in management and use) are shown in Table 5a and Table 5b.

Table 5a. Current threats on the species Cavia tschudii

\begin{tabular}{|c|c|c|c|c|}
\hline Code & Name od acitivity & Intensity & Impact & Synthetic description \\
\hline G05.07 & $\begin{array}{l}\text { improperly } \\
\text { implemented } \\
\text { protective measures } \\
\text { or their lack }\end{array}$ & $\mathrm{B}$ & - & no active protection \\
\hline K03.04 & predation & $A$ & - & $\begin{array}{l}\text { predators (birds, mam- } \\
\text { mals, reptiles) can sig- } \\
\text { nificantly reduce the po- } \\
\text { pulation }\end{array}$ \\
\hline M01.03 & $\begin{array}{l}\text { floods } \\
\text { and increased rainfall }\end{array}$ & $\mathrm{B}$ & 0 & not observed \\
\hline A03.02 & intensive mowing & B & - & $\begin{array}{l}\text { at a given site, the cavia } \\
\text { population may be ex- } \\
\text { posed to the effects } \\
\text { of mowing }- \text { the des- } \\
\text { truction of corridors in } \\
\text { dense vegetation }\end{array}$ \\
\hline
\end{tabular}

Table 5b. Future threats of Cavia tschudii

\begin{tabular}{|c|c|c|c|c|}
\hline Code & Name od acitivity & Intensity & Impact & Synthetic description \\
\hline M01.03 & $\begin{array}{l}\text { floods } \\
\text { and increased rainfall }\end{array}$ & B & - & $\begin{array}{l}\text { random factor that can } \\
\text { lower you significantly } \\
\text { population size }\end{array}$ \\
\hline A03.02 & intensive mowing & B & - & $\begin{array}{l}\text { mowing grasses, espe- } \\
\text { cially during the bree- } \\
\text { ding season, can kill } \\
\text { young specimens and } \\
\text { increase predator pre- } \\
\text { ssure }\end{array}$ \\
\hline
\end{tabular}

\section{CONCLUSIONS}

Montane Guinea Pig is not protected. Its population is considered to be stable. Unfortunately, due to insufficient monitoring of the species, we do not know its exact number. Monitoring should be carried out regularly, every 3 years. Environmental factors are crucial for its occurrence - the type of terrain (the most preferable is a closed area), the height 
of the vegetation (vegetation with a height of $50 \mathrm{~cm}$ gives the animal sufficient shelter), and the food base (especially grasses which are their main food). Montane Guina Pig (Cavia tschudii) is also found in the protected area of the Junin National Reserve in Peru. It seems that the use of passive protection is a sufficient way to protect this species. The adopted monitoring methodology can also be used for other species of the genus of cavia:Cavia aperea, Cavia fulgida, Cavia magna, Cavia intermedia (Lacher 2016).

\section{REFERENCES}

Asher M., Spinelli de Oliveira E., Sachser N. 2004. Social System and Spatial Organization of Wild Guinea Pigs (Cavia aperea) in a Natural Population. J. Mammal. 85, 788-796.

Candel M. 2019. A new echimyid genus (Rodentia, Caviomorpha) in Central Argentina: uncovered diversity of a Brazilian group of mammals in the Pleistocene. J. Paleontol. 94, 1937-2337.

Cavia tschudii, https://inaturalist.ca/taxa/43810-Cavia-tschudii, access: 9.06.2020.

Dunnum J.L. 2015. Family: Caviidae, in: Mammals of South America, vol. 2. Rodents, eds. J.L. Patton, U.FJ. Pardiñas, G. D'Elía. The University of Chicago Press, 690-726.

Eisenberg J.F., Redford K.H. 1999. Mammals of the Neotropics, in: The Central Neotropics: Ecuador, Peru, Bolivia, Brazil, vol. 3. The Central Neotropics, ed. H.F. Harper, University of Chicago Press, 256.

IUCN. 2016. Czerwona lista gatunków zagrożonych stworzona przez IUCN, www.iucnredlist.org, access: 9.06.2020. [in Polish]

Lacher T.E. 2016. Family: Caviidae, in: Handbook of Mammals of the World, vol. 6. Lagomorphs and Rodents, ed. W. Wilson, D.E. Lacher, R.A. Mittermeier, Barcelona, Lynx Editions, 57-59.

Makomaska-Juchiewicz M., Bonk M. (red.). 2015. Monitoring gatunków zwierząt. Przewodnik metodyczny, cz. IV. Warszawa, GIOŚ. [in Polish]

Ortiz P.E., Jayat J.P. 2012. Range extension of Cavia tschudii Fitzinger 1867. Mammalia: Caviidae and first record in Catamarca. Northwestern Argentina. Check List 8, 782-83.

\section{PROPOZYCJA MONITORINGU GATUNKU KAWII GÓRSKIEJ W PERU}

Streszczenie. W niniejszym artykule przedstawiono propozycję monitoringu gatunku średniej wielkości gryzonia Ameryki Południowej - kawii górskiej. Populacja tego gatunku nie jest na bieżąco monitorowana, nie można więc określić, ile dokładnie osobników znajduje się na wolności. W ostatnich latach obszar siedliska został jednak znacznie zmniejszony. Konieczne jest więc opracowanie metod jego monitoringu. Zaproponowano monitoring na kilku obszarach występowania gatunku: w prowincji dzielnicy Lima - Cercado de Lima, Rezerwacie Narodowym Junín oraz w prowincji miasta Ambo. Głównym celem artykułu jest określenie wskaźników stanu populacji, wskaźników jakości siedliska oraz ustalenie przykładowych terminów i częstotliwości badań.

Słowa kluczowe: kawia górska, monitoring, gryzoń, populacja, wskaźnik. 